\section{Influence of Obesity on the Antilipolytic Effect of Insulin in Isolated Human Fat Cells Obtained Before and After Glucose Ingestion}

Peter Arner, Jan Bolinder, Peter Engfeldt, Johan Hellmér, and Jan Östman

Karolinska Institute, Department of Medicine and the Research Center at Huddinge Hospital, Huddinge, Sweden bstract. The antilipolytic effect of insulin was studied in 9 obese and 10 age- and sex-matched subjects of normal weight. Isolated fat cells were taken before and $1 \mathrm{~h}$ after an $100 \mathrm{~g}$ oral glucose load. Insulin inhibition of basal and isoprenaline-induced rates of lipolysis were determined by using a sensitive bioluminescent glycerol assay. When compared with the controls, the obese group showed a lower glucose tolerance, a higher insulin secretion, and a lower specific insulin receptor binding per adipocyte surface area, which would suggest an insulinresistant state. Before oral glucose, however, the sensitivity of the antilipolytic effect of insulin was enhanced 10-fold in obesity $(P<0.01)$, but the maximum antilipolytic effect was not altered. Glucose ingestion induced a 1025 -fold increase in insulin sensitivity $(P<0.01)$ and a $10 \%$ but not significant increase in specific adipocyte insulin receptor binding in the nonobese group. In the obese group, however, neither the insulin binding nor the antilipolytic effect of the hormone was increased by oral glucose. After oral glucose, insulin sensitivity was similar in the two groups. The concentration of the hormone which produced a half maximum effect was about $1 \mu \mathrm{U} /$ $\mathrm{ml}$. Similar results were obtained with insulin inhibition of basal and isoprenaline-stimulated glycerol release. It is concluded that, after an overnight fast, the sensitivity of the antipolytic effect of insulin is markedly enhanced in adipocytes of "insulin-glucose resistant" obese subjects, presumably because of alterations at postreceptor levels

Address all correspondence to Dr. Arner, Department of Medicine, Huddinge Hospital, S-141 86 Huddinge, Sweden. 1983.

Received for publication 8 June 1983 and in revised form 4 November

J. Clin. Invest.

(c) The American Society for Clinical Investigation, Inc. 0021-9738/84/03/0673/08 \$1.00

Volume 73, March 1984, 673-680 of insulin action. In obesity, the antilipolytic effect of insulin seems normal after glucose ingestion. Furthermore, in adipocytes of subjects of normal weight, oral glucose rapidly stimulates the sensitivity of the antilipolytic effect of insulin, apparently because of changes at postreceptor sites. This short-term regulation of insulin action following the ingestion of glucose does not seem to be present in obesity.

\section{Introduction}

It is well known that the hypoglycemic effect of insulin is attenuated in obesity. This is evidenced by an apparent decrease in the sensitivity and responsiveness (maximum action) of insulin $(1,2)$. Sensitivity usually reflects insulin binding, whereas responsiveness mirrors insulin action at postreceptor levels (3). A decrease in insulin receptor binding (4), as well as in the sensitivity and responsiveness of insulin stimulation of glucose transport $(5,6)$, has been demonstrated in obesity by using human adipocytes. Thus, insulin resistance in obesity may be due to a combination of receptor and postreceptor defects in insulin action on glucose transport. However, insulin has several other primary actions. One of the more important is the inhibition of lipolysis in fat cells. Whether this insulin effect is altered in obese subjects is a matter of uncertainty. This may partly be due to the methodological difficulties of estimating lipolysis, which occurs at a slow rate in human fat cells (7). We have recently developed an ultrasensitive bioluminescent technique for the determination of glycerol release from human adipocytes (8). This allows a detailed analysis to be made of the dose-response relationship of insulin inhibition of lipolysis in microsamples of these cells (9). Furthermore, insulin resistance represents a chronic change in insulin action which develops slowly. However, acute adaptation of the antilipolytic effect of insulin has recently been demonstrated in man. Thus, human fat cells obtained $1 \mathrm{~h}$ after glucose ingestion show a marked increase in insulin sensitivity (10).

In the present study, the antilipolytic effect of insulin and insulin receptor binding were studied in isolated fat cells obtained from 9 obese subjects and 10 age- and sex-matched subjects of 
normal weight. Subcutaneous fat was obtained before and $1 \mathrm{~h}$ after the oral ingestion of $100 \mathrm{~g}$ of glucose. A marked increase in the sensitivity of the antilipolytic of insulin was observed in obesity before glucose ingestion. In contrast to the nonobese subjects, however, no further increase in insulin sensitivity could be demonstrated in the obese subjects after glucose ingestion.

\section{Methods}

Subjects. The study groups consisted of 10 healthy subjects of normal weight and 9 weight-stable obese subjects who were otherwise healthy. They are described in Table I. The onset of obesity occurred in childhood. None of the obese subjects had recently been on a slimming program involving caloric restriction or physical exercise. All subjects were on a diet consisting of $\sim 45 \%$ carbohydrates, $35 \%$ fat, and $20 \%$ protein, which had been calculated from a 24-h recall. None had a recent history of the intake of any drug known to affect glucose tolerance, insulin release, or adipose tissue metabolism. The subjects were examined in the outpatient's department at 8 a.m. after an overnight fast. The study was authorized by the hospital's Ethical Committee. Informed consent was obtained from all subjects.

Protocol. A biopsy of subcutaneous adipose tissue $(\sim 0.5 \mathrm{~g})$ was taken from the gluteal region under local anesthesia. Pilocarpin was injected in a way that did not affect adipose tissue metabolism (11). After the biopsy, $100 \mathrm{~g}$ of glucose was ingested and samples of venous blood were drawn for the determination of plasma glucose (12) and plasma immunoreactive insulin (13) at $0,15,30,45,60,90$, and 120 $\mathrm{min}$. At $60 \mathrm{~min}$, another fat biopsy was taken. Isolated fat cells were prepared by Rodbell's method (14).

Lipolysis determination. Isolated fat cells were incubated at a final concentration of $\sim 20,000 \mathrm{cells} / \mathrm{ml}(2 \%$, vol/vol) in Krebs-Henseleit bicarbonate buffer containing glucose $(2 \mathrm{mg} / \mathrm{ml})$, albumin $(40 \mathrm{mg} / \mathrm{ml})$, isopropyl noradrenaline ( 0 or $\left.6 \times 10^{-6} \mathrm{~mol} / \mathrm{liter}\right)$, and insulin $(0,0.1$, $0.25,1,2.5,10,25,100,250$, and $1000(\mu \mathrm{U} / \mathrm{ml})$. It was not always possible to use all of the insulin concentrations. The albumin:free fatty acid molar ratio was 3:1. It was necessary to use a high glucose concentration in the medium in order to obtain a constant antilipolytic effect of insulin in the isoprenaline experiments, since fat cells sometimes were resistant to insulin at glucose concentrations below $2 \mathrm{mg} / \mathrm{ml}(9)$. Each incubation was run in duplicate at $37^{\circ} \mathrm{C}$ with $\mathrm{O}_{2}: \mathrm{CO}_{2}(95: 5)$ as the gas phase. The total incubation volume was $0.2 \mathrm{ml}$. After incubation, aliquots of the medium were removed for the determination of glycerol, by using a bioluminescent technique that has been described in detail (8). The detection limit for glycerol was $0.5 \mu \mathrm{mol} / \mathrm{liter}$. The coefficient of variance for glycerol release in one subject was $6 \%$.

Determination of insulin binding. Isolated fat cells were incubated in duplicate or triplicate at a final cell concentration of $4 \%$ (vol/vol) for $60 \mathrm{~min}$ at $24^{\circ} \mathrm{C}$ in Krebs-Henseleit bicarbonate buffer ( $\mathrm{pH} \mathrm{7.4)} \mathrm{containing}$ albumin $(40 \mathrm{mg} / \mathrm{ml})$, glucose $(2 \mathrm{mg} / \mathrm{ml})$, mono--125I-(Tyr $\left.A_{14}\right)$-insulin $(0.05 \mathrm{pmol} / \mathrm{ml})$, and unlabeled insulin $(0-50 \mathrm{pmol} / \mathrm{ml})$. The total incubation volume was $0.2 \mathrm{ml}$. The binding reaction was terminated by adding $2.5 \mathrm{ml}$ of ice-cold saline and rapidly centrifuging the cells through $0.7 \mathrm{ml}$ of silicon oil (15). The supernatant cells were then removed for determination of radioactivity. Nonspecific binding was measured in the presence of $20 \mathrm{nmol} / \mathrm{ml}$ of unlabeled insulin. All data were corrected for nonspecific binding. Specific tracer binding increased in a linear fashion when fat cells were incubated in concentrations ranging from $1-33 \%$ (vol/vol). With the use of this method, $(a)$ insulin degradation is negligible, $(b)$ nonspecific binding is low, about $4 \%$, and $(c)$ a steady state of insulin binding is always reached after $\mathbf{4 0} \mathrm{min}$ and maintained for at least $120 \mathrm{~min}$ (16). The coefficient of variance for insulin binding to isolated fat cells was $7 \%$ in one subject.

Fat cell determination. Fat cell size was measured (17), and mean fat cell volume and mean fat cell weight were calculated by using previously described methods (18).

Chemicals. Crystalline glucagon-free porcine insulin was kindly supplied by Vitrum AB, Sweden. Mono- ${ }^{125}$ I-(Tyr $A_{14}$ )-insulin was obtained from Novo Research Institute, Copenhagen, Denmark and bovine serum albumin (fraction V) from the Armour Pharmaceutical Co., England.

Expression of the results. Glycerol release and insulin binding were expressed per number of cells. Insulin binding was also expressed per cell surface area. The number of cells incubated was determined by division of the lipid weight of the incubated sample by the mean fat cell weight. Insulin responsiveness was defined as glycerol release in the absence of insulin minus glycerol release at the maximum effective insulin concentration. Insulin sensitivity was determined in three ways. First, the ascending part of the mean dose-response curves for the antilipolytic effect of insulin was linearized by using a plot of log insulin concentration versus the $\log (y / 100-y)$, where y denotes the inhibition of lipolysis at a particular insulin concentration, which was expressed as a percentage of the maximum inhibitory effect. The apparent halfmaximum effect $\left(E_{50}\right)^{1}$ was obtained from the point where the line intersects the abscissa at zero. This plot has been described in detail elsewhere (19). Differences in left-right position between linearized mean dose-response curves were tested statistically (see below). Significant differences in the slope and the intercept between lines were considered to represent differences in insulin sensitivity. Secondly, the individual $\mathrm{ED}_{50}$-values were calculated from each single dose-response curve. Thirdly, the lowest concentration of insulin used that gave a significant inhibition of glycerol release in the obese and nonobese groups, respectively, was determined. The insulin-binding experiments were expressed by competition curves and by Scatchard's method (20).

Statistical methods. The reported values represent the mean \pm standard error of the mean. The student's paired and unpaired $t$ test, linear regression analysis by the method of least squares, and the $F$ distribution test (21) were used for statistical evaluation of the results.

\section{Results}

Blood glucose, plasma insulin, and fat cell size. Table I shows that two of the obese subjects (Nos. 4 and 8 ) had an elevated fasting blood glucose at the time of the investigation. They were studied on two other occasions and the values were then normal. The obese subjects had moderate fasting hyperinsulinemia (Table I). Their bodyweight was $75 \%$ higher and their fat cells were $35 \%$ larger than those of the nonobese subjects (Table I). The results of a $100 \mathrm{~g}$ oral glucose load are shown in Fig. 1. In both groups, the blood glucose and plasma insulin were significantly elevated at $60 \mathrm{~min}$ when the second biopsy was taken. In comparison with the nonobese subjects, the obese ones displayed significantly higher glucose and insulin values over a 2 -h period, which indicated an insulin-resistant state. Oral glucose did not affect fat cell size (data not shown).

1. Abbreviation used in this paper: $\mathrm{ED}_{50}$, half-maximum effect. 
Table I. Clinical Data of the Study Groups

\begin{tabular}{|c|c|c|c|c|c|c|c|}
\hline Subjects & & Sex & Age & Body weight & $\begin{array}{l}\text { Blood } \\
\text { glucose }\end{array}$ & $\begin{array}{l}\text { Plasma } \\
\text { insulin }\end{array}$ & $\begin{array}{l}\text { Fat cell } \\
\text { volume }\end{array}$ \\
\hline & & & $y r$ & \% of average & $\mathrm{mmol} / \mathrm{liter}$ & $\mu U / m l$ & $\mathrm{~mm}^{3} \times 10^{-6}$ \\
\hline \multirow[t]{11}{*}{ Nonobese } & 1 & $\mathrm{~F}$ & 23 & 96 & 4.2 & 4.6 & 1017 \\
\hline & 2 & $\mathrm{~F}$ & 24 & 101 & 4.2 & 4.1 & 1245 \\
\hline & 3 & $\mathbf{M}$ & 25 & 101 & 5.1 & 3.2 & 810 \\
\hline & 4 & $\mathrm{~F}$ & 31 & 102 & 5.2 & 6.1 & 966 \\
\hline & 5 & $\mathbf{M}$ & 28 & 95 & 5.0 & 10.2 & 880 \\
\hline & 6 & $\mathbf{M}$ & 30 & 96 & 5.4 & 6.2 & 940 \\
\hline & 7 & $\mathbf{F}$ & 33 & 95 & 4.3 & 2.5 & 881 \\
\hline & 8 & $\mathrm{~F}$ & 40 & 110 & 5.2 & 4.0 & 1172 \\
\hline & 9 & $\mathbf{F}$ & 46 & 91 & 3.9 & 2.7 & 618 \\
\hline & 10 & $F$ & 50 & 97 & 4.1 & 2.8 & 999 \\
\hline & Mean \pm SE & $7 / 3$ & $33 \pm 3$ & $98 \pm 2$ & $4.8 \pm 0.2$ & $4.6 \pm 0.7$ & $953 \pm 53$ \\
\hline \multirow[t]{10}{*}{ Obese } & 1 & $\mathbf{M}$ & 25 & 205 & 4.3 & 26.2 & 1511 \\
\hline & 2 & $\mathrm{~F}$ & 38 & 196 & 4.8 & 16.7 & 1454 \\
\hline & 3 & $\mathbf{M}$ & 43 & 132 & 5.0 & 8.2 & 860 \\
\hline & 4 & $\mathrm{~F}$ & 25 & 187 & 7.3 & 15.2 & 1154 \\
\hline & 5 & $F$ & 35 & 147 & 3.8 & 3.1 & 973 \\
\hline & 6 & F & 35 & 170 & 4.4 & 3.7 & 1329 \\
\hline & 7 & $F$ & 27 & 179 & 4.3 & 12.6 & 1568 \\
\hline & 8 & $\mathbf{F}$ & 33 & 169 & 6.5 & 16.2 & 1477 \\
\hline & 9 & $\mathrm{~F}$ & 21 & 168 & 4.3 & 6.6 & 1340 \\
\hline & Mean \pm SE & $7 / 2$ & $31 \pm 2$ & $173 \ddagger \pm 8$ & $5.0 \pm 0.4$ & $12.1^{*} \pm 2.5$ & $1296^{*} \pm 83$ \\
\hline
\end{tabular}

The subjects were investigated after an overnight fast. The average body weight was obtained from tables computed by Documenta Geigy (33). The significance of the differences between nonobese and obese subjects were determined with the unpaired $t$ test. ${ }^{*} P<0.01 ; \ddagger P<0.001$.

Insulin binding. Insulin receptor binding to adipocytes obtained after an overnight fast is shown in Fig. 2. When binding was expressed per number of cells, the competition curves showed no significant differences between obese and nonobese subjects. The mean Scatchard plots for the two groups were curvilinear and were almost identical. However, insulin binding was definitely lower in subjects with obesity when it was expressed per cell surface area. The mean competition curves in the obese and the nonobese groups were significantly different over the entire range of insulin concentrations tested. Transformation of the binding by using Scatchard's method (20) showed that the shift of the curve to the left in obese subjects was almost parallel to that in the nonobese. This indicates that the decrease of binding in obesity was largely due to a loss in total insulinbinding sites. However, insulin receptor number was not determined in this study, since it has recently been recognized (22) that the determination of total binding capacity from curvilinear Scatchard plots may be very inaccurate.

Insulin receptor binding was almost the same before and after glucose ingestion in the obese subjects (Fig. 3). In the nonobese subjects, however, insulin receptor binding was, on the average, $10 \%$ higher after the oral glucose load than before it, but the difference was not statistically significant (Fig. 3). In a previous study of eight nonobese subjects (10), we also observed a small increase in insulin receptor binding in postglucose adipocytes, but this difference was statistically significant. The reasons for the discrepancy in results are not clear.

There was no correlation between fat cell volume and tracer insulin receptor binding (data not shown).

Sensitivity of the antilipolytic effect of insulin. Mean doseresponse curves for the insulin inhibition of basal glycerol release are shown in Fig. 4. The study performed before oral glucose showed a marked shift to the left in the dose-response curve for obese subjects when compared with that for nonobese subjects. This suggests an enhanced insulin sensitivity in obesity. The lowest concentration of insulin that yielded a statistically significant antilipolytic effect was $0.25 \mu \mathrm{U} / \mathrm{ml}$ in obese subjects and $2.5 \mu \mathrm{U} / \mathrm{ml}$ in control subjects. The mean $\mathrm{ED}_{50}$ for insulin inhibition of basal lipolysis was $10 \mu \mathrm{U} / \mathrm{ml}$ in the nonobese group and $0.6 \mu \mathrm{U} / \mathrm{ml}$ in the obese group, which was a more than $15-$ fold difference. This difference was statistically significant $(F$ $=13.33, p<0.01)$ when left-right positions of linearized doseresponse curves were compared in the manner described in Methods. When the antilipolytic effect of insulin was measured in postglucose adipocytes, insulin sensitivity was similar in both groups; the mean $\mathrm{ED}_{50}$ for insulin being $\sim 0.5 \mu \mathrm{U} / \mathrm{ml}$. In the 

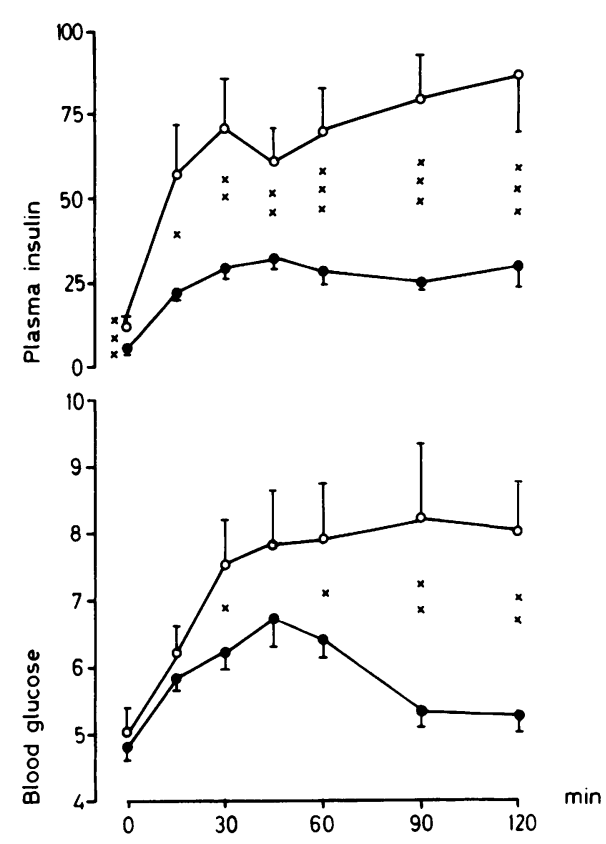

Figure 1. Results of oral glucose tests in 10 nonobese $(\bullet)$ and 9 obese (o) subjects. The subjects were given a $100 \mathrm{~g}$ oral glucose load, and plasma insulin $(\mu \mathrm{U} / \mathrm{ml})$ and blood glucose levels (mmol/liter) (mean $\pm \mathrm{SE}$ ) were followed for $120 \mathrm{~min}$. The unpaired $t$ test was used to statistically compare the data in the two groups. NS, not significant, $\times, P<0.05 ; \times \times, P<0.025 ; \times \times \times, P<0.01$.

nonobese group, there was a 20 -fold increase in insulin sensitivity after oral glucose as judged by the mean $\mathrm{ED}_{50}$ value which decreased from 10 to $0.5 \mu \mathrm{U} / \mathrm{ml}$. This difference in insulin sensitivity was statistically significant $(F=14.94 ; P<0.01)$ and is similar to previous results reported for nonobese subjects (10).
In the obese group, however, there was no change in insulin sensitivity after oral glucose; the mean $\mathrm{ED}_{50}$ values were 0.6 and $0.5 \mu \mathrm{U} / \mathrm{ml}$ of insulin in pre- and postglucose adipocytes.

The mean dose-response relationship for the insulin inhibition of the isoprenaline-induced rate of glycerol release is shown in Fig. 5. Again, a marked increase in insulin sensitivity was observed in adipocytes obtained from obese subjects after an overnight fast as compared with nonobese subjects. The lowest concentration of insulin that yielded a statistically significant antilipolytic effect after an overnight fast was $0.25 \mu \mathrm{U} /$ $\mathrm{ml}$ in obese subjects and $1 \mu \mathrm{U} / \mathrm{ml}$ in control subjects. Before oral glucose, the mean $\mathrm{ED}_{50}$ for insulin was $1.5 \mu \mathrm{U} / \mathrm{ml}$ in the obese group and $10 \mu \mathrm{U} / \mathrm{ml}$ in the nonobese group, which represents an almost sevenfold difference in sensitivity. This difference was statistically significant when the positions of the linearized mean dose-response curves were compared $(F=10.22$, $P<0.05$ ). In adipocytes obtained after the oral glucose load, insulin sensitivity was, however, almost identical in the two groups; the mean $\mathrm{ED}_{s 0}$ being $1 \mu \mathrm{U} / \mathrm{ml}$. The latter results are also similar to those described above for insulin inhibition of basal lipolysis. The effect of oral glucose on insulin sensitivity was also evaluated. In the nonobese group, insulin sensitivity increased 10 -fold after oral glucose and the mean $\mathrm{ED}_{50}$ value decreased from 10 to $1 \mu \mathrm{U} / \mathrm{ml}$ of insulin $(F=58,52, P<0.01)$. In the obese group, however, insulin sensitivity was similar in pre- and postglucose adipocytes and the mean $\mathrm{ED}_{50}$ values were 1.5 and $1 \mu \mathrm{U} / \mathrm{ml}$, respectively.

Insulin sensitivity was also evaluated in the obese and nonobese subjects by comparing the individual $\mathrm{ED}_{50}$ values for insulin inhibition of basal and isoprenaline-stimulated lipolysis (Table II). These results were similar to those obtained with mean dose-response curves. Thus, in the fasting state, the $\mathrm{ED}_{50}$ values for insulin inhibition of both basal and isoprenaline-
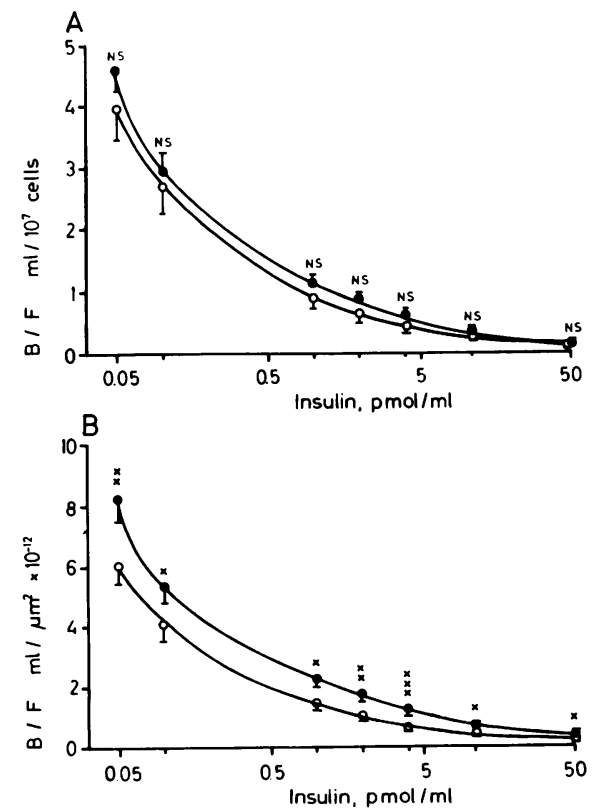
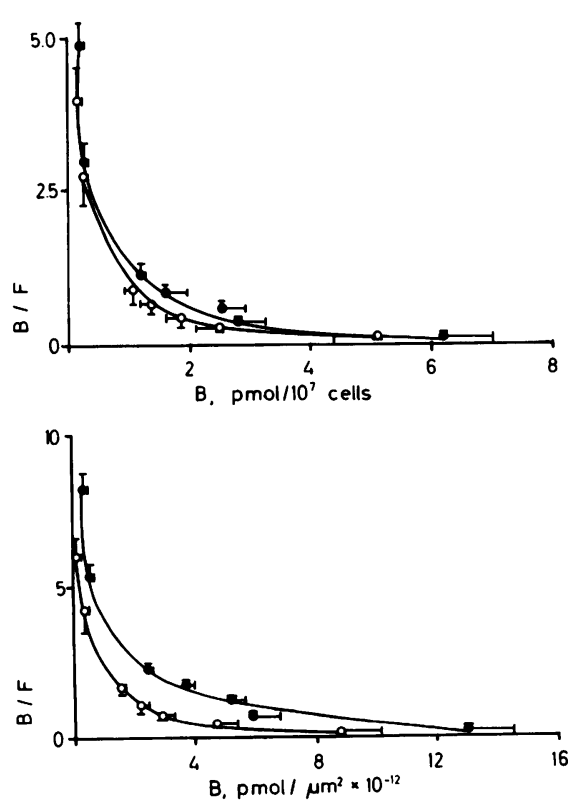

Figure 2. Specific insulin binding to isolated fat cells of 10 nonobese ( $\bullet$ ) and 9 (o) obese subjects. Fat cells were obtained after an overnight fast. Binding data are presented as competition plots (left) and Scatchard plots (right), where B/F denotes bound/free and $B$ denotes bound hormone. $(A)$ binding expressed per number of fat cells, $(B)$ binding expressed as fat-cell surface area. 


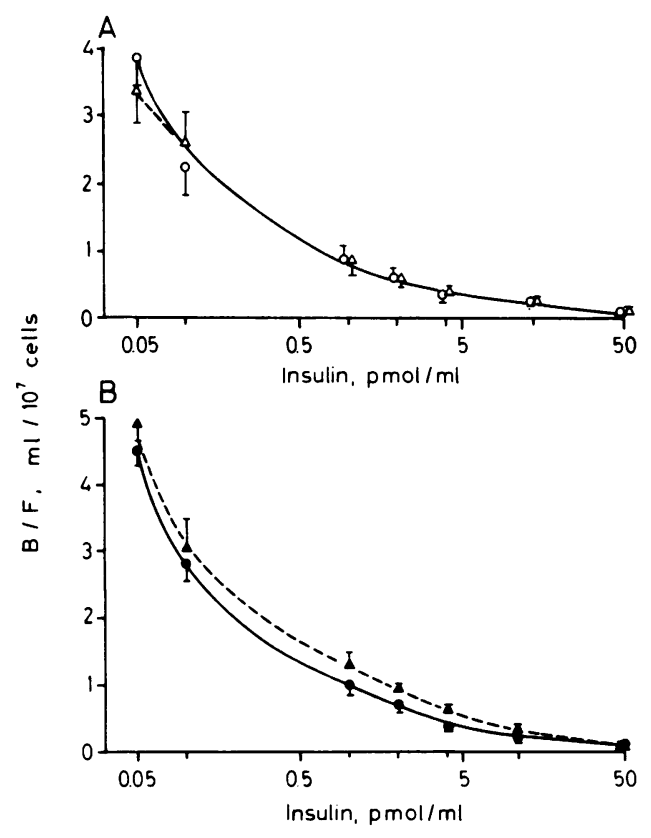

Figure 3. Effect of oral glucose on specific insulin binding to isolated fat cells of $(A) 9$ obese and $(B) 10$ nonobese subjects. Fat cells were obtained before (solid lines) and $60 \mathrm{~min}$ after (broken lines) a $100 \mathrm{~g}$ oral glucose load. Binding data are presented as competition plots. See legends to Figs. 1 and 2 for further details.

induced lipolysis were significantly higher in the nonobese than in the obese group. In the nonobese group, significantly higher $\mathrm{ED}_{s 0}$ values for insulin inhibition of both basal and isoprenalinestimulated lipolysis were recorded in preglucose fat cells as compared with postglucose adipocytes. These differences were not observed in the obese group. After oral glucose, the $\mathrm{ED}_{s_{0}}$ values for insulin were similar in obese and in nonobese subjects, in both the basal state and the presence of isoprenaline. The individual $\mathrm{ED}_{50}$ values for insulin were not correlated with the rate of glycerol release in the absence of insulin (data not shown).

Responsiveness of the antilipolytic effect of insulin. It appears from the mean dose-response curves in Figs. 4 and 5 that insulin responsiveness after an overnight fast was also enhanced in the obese group. When individual values were analyzed, maximum insulin-induced inhibition of the basal rate of glycerol release was $4.4 \pm 1.3 \mu \mathrm{mol} / 10^{7}$ cells per $2 \mathrm{~h}$ in the obese group and $2.1 \pm 0.4 \mu \mathrm{mol} / 10^{7}$ cells per $2 \mathrm{~h}$ in the nonobese group. This difference, however, was of only borderline statistical significance $(0.01>P>0.05)$. The individual values for maximum insulin inhibition of isoprenaline-induced lipolysis were almost identical in the obese and the nonobese groups, being $10.4 \pm 2.4$ and $9.6 \pm 3.4 \mu \mathrm{mol} / 10^{7}$ cells per $2 \mathrm{~h}$, respectively. Insulin responsiveness depended on the lipolysis rate, as shown for preglucose adipocytes in Fig. 6. In the entire material (obese and nonobese, basal and isoprenaline experiments), there was a strong association between the rate of glycerol release in the absence of insulin and the maximum insulin-induced inhibition of glycerol release $(r=0.89 ; P<0.01)$. No differences were observed be- tween studies in the basal state and in the presence of isoprenaline $(F=2.9)$, or between results in obese and nonobese subjects $(F=1.4)$. Positive correlations between the rate of glycerol release and insulin responsiveness were also observed for basal lipolysis in obese $(r=0.987)$ and control subjects $(r=0.843)$ as well as for isoprenaline-induced lipolysis in obese $(r=0.815)$ and nonobese subjects $(r=0.942)$. These results indicate that insulin responsiveness was similar in obese and nonobese subjects when the insulin action occurred at identical rates of lipolysis.

Basal and isoprenaline-induced rates of lipolysis. After an overnight fast, the basal rate of glycerol release was $50 \%$ higher in obese than in nonobese subjects, i.e., $6.2 \pm 1.5$ and $4.2 \pm 1.0$ $\mu \mathrm{mol} / 10^{7}$ cells per $2 \mathrm{~h}$, respectively. This is in accordance with previous findings (7). The rates of isoprenaline-induced glycerol release were, however, similar in the two groups after an overnight fast, $29.7 \pm 6.9$ and $28.9 \pm 6.7 \mu \mathrm{mol} / 10^{7}$ cells per $2 \mathrm{~h}$, respectively.

Neither in the obese nor in the nonobese group did oral glucose affect the basal or the isoprenaline-induced rates of lipolysis (data not shown).

\section{Discussion}

The present results on antilipolysis in "insulin-resistant" obese subjects differ substantially from those previously reported for glucose metabolism. Both the sensitivity and the responsiveness of insulin stimulation of glucose transport have been shown to

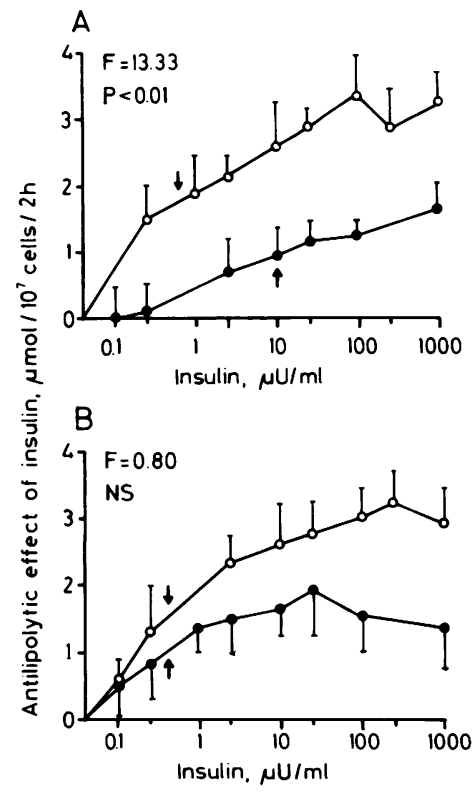

Figure 4. Insulin inhibition of basal glycerol release in isolated fat cells of 10 nonobese (solid symbols) and 9 obese (open symbols) subjects. Fat cells were incubated with various concentrations of insulin. The antilipolytic effect of insulin was calculated as the rate of glycerol release in the absence of insulin minus the rate in the presence of insulin. The mean dose-response curves are shown. For statistical comparison, the ascending part of these curves was linearized using log-logit transformation, as described in Methods. The position of the lines in the plot was determined by using linear regression analysis. The statistical

difference in the position between lines was determined by the $F$-distribution test (21). The $F$ value and the level of significance are given in the graph. The concentration of insulin giving the $\mathrm{ED}_{50}$ is obtained where the regression line crosses the abscissa at zero. This is indicated in the dose-response curve by an arrow. $(A)$ Fat cells obtained before oral glucose, $(B)$ fat cells obtained $60 \mathrm{~min}$ after oral glucose. See legend to Fig. 1 for further details. 


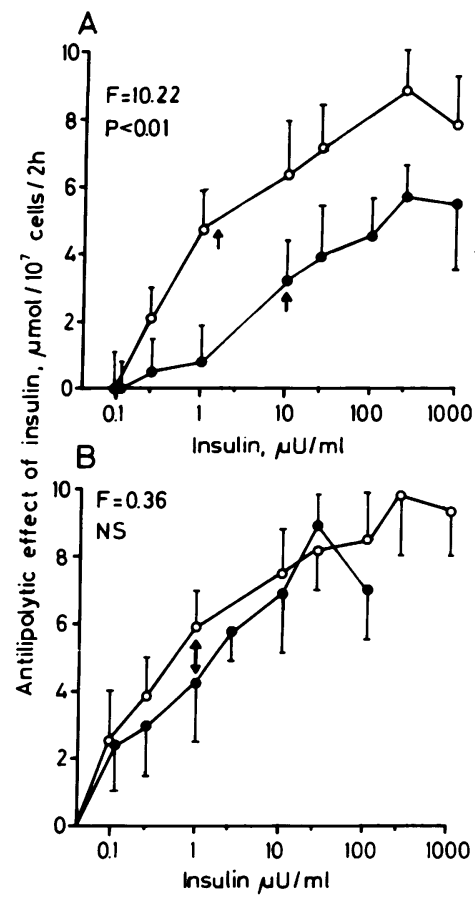

Figure 5. Insulin inhibition of isoprenaline-induced lipolysis in isolated fat cells of 10 nonobese and 9 obese subjects. Fat cells were incubated in the presence of isoprenaline and various insulin concentrations. Other details are the same as in Fig. 4.

be reduced in adipocytes obtained from obese subjects after an overnight fast $(5,6)$. We observed a marked increase in sensitivity, and a normal or increased responsiveness of the antilipolytic effect of insulin in this situation. Thus, insulin resistance in obese human fat cells does not seem to be an overall phenomenon. It may even solely involve glucose metabolism since primary actions other than glucose transport and antilipolysis have not yet been investigated. Insulin sensitivity in this study was evaluated in three ways. Individual $\mathrm{ED}_{\mathbf{5 0}}$ values were investigated. Mean dose-response curves for the obese and nonobese groups were analyzed. Finally, the lowest concentration of insulin that yielded a significant antilipolytic effect was determined. Increased sensitivity after an overnight fast was ob-

served in obese subjects by using all three methods. Furthermore, the results were similar in studies of insulin inhibition of basal and isoprenaline-induced lipolysis.

Our findings differ also from previous reports on the antilipolytic effect of insulin on adipose tissue obtained from obese subjects after an overnight fast. Jacobsson et al. (23) found normal insulin inhibition of catecholamine-induced glycerol release in adipose tissue segments. In our study, insulin inhibition of basal lipolysis in segments of adipose tissue was normal (19). Pedersen et al. (6) found a decreased insulin inhibition of catecholamine-induced lipolysis in isolated adipocytes. There may be several reasons for the discrepancy in the results of investigations of antilipolysis in obesity. Previously, less sensitive enzyme methods were used to determine the glycerol production which occurs at low rates in human fat cells (7). High fat cell concentrations have been used to obtain measurable glycerol values. Fat cells or fat segments were previously incubated at concentrations corresponding to $150,000-500,000 \mathrm{cells} / \mathrm{ml}$. At these fat cell concentrations, endogenous metabolites, such as free fatty acids and adenosine, may accumulate and inhibit lipolysis in human fat cells $(24,25)$ or alter the sensitivity of the antilipolytic effect of insulin (26). The influence of endogenous metabolites is negligible at the adipocyte concentration $(20,000 \mathrm{cells} / \mathrm{ml})$ used in this study. Furthermore, insulin inhibition of basal and catecholamine-induced lipolysis in human fat cells has recently been found to be modified by the glucose concentration in the medium (9). The maximum insulin-induced inhibition of lipolysis occurred when the concentration of glucose was $2 \mathrm{mg} / \mathrm{ml}(9)$. The glucose concentration used previously was lower than in the present study, i.e., 0.2 (23) and $1 \mathrm{mg} / \mathrm{ml}$ (6), respectively. Thus, variations in incubation conditions may at least partly explain the differences in results obtained with antilipolysis in obesity. However, other factors, such as the type of obesity, may also play a role. We investigated subjects with childhood obesity, who were only moderately hyperinsulinemic. Insulin action may be different in those adult-onset obese subjects, who tend to be more hyperinsulinemic. Finally, the location of the adipose tissue may be of importance for antilipolysis in

Table II. Concentrations of Insulin-producing $E D_{s o}$ of the Lipolysis Rate

\begin{tabular}{|c|c|c|c|c|c|c|}
\hline \multirow[b]{3}{*}{ Study group } & \multicolumn{6}{|c|}{$\mathrm{ED}_{s 0}(\mu \mathrm{U} / \mathrm{ml}, \mathrm{Mean} \pm \mathrm{SE})$} \\
\hline & \multicolumn{3}{|c|}{ Basal state } & \multicolumn{3}{|c|}{ Isoprenaline } \\
\hline & $\begin{array}{l}\text { Before } \\
\text { glucose }\end{array}$ & $\begin{array}{l}\text { After } \\
\text { glucose }\end{array}$ & $P$, before vs. after & $\begin{array}{l}\text { Before } \\
\text { glucose }\end{array}$ & $\begin{array}{l}\text { After } \\
\text { glucose }\end{array}$ & $P$, before vs. after \\
\hline Nonobese & $11.9 \pm 4.9$ & $2.5 \pm 1.2$ & $<0.025$ & $7.5 \pm 3.0$ & $0.6 \pm 0.2$ & $<0.02$ \\
\hline Obese & $0.8 \pm 0.2$ & $1.4 \pm 0.5$ & NS & $0.8 \pm 1.0$ & $0.8 \pm 1.8$ & NS \\
\hline$P$, nonobese vs. obese & $<0.02$ & NS & & $<0.05$ & NS & \\
\hline
\end{tabular}

Isolated fat cells obtained from 10 nonobese and 9 obese subjects were incubated in the basal state or with isoprenaline (6 $\mu \mathrm{mol} / \mathrm{liter})$. The doseresponse relationships for insulin inhibition of basal or isoprenaline-induced glycerol release were evaluated in each subject and the individual $\mathrm{ED}_{s 0}$-values were determined. Statistical analysis was done by using the paired $t$ test (within groups) and the unpaired $t$ test (between groups). NS, not significant. 


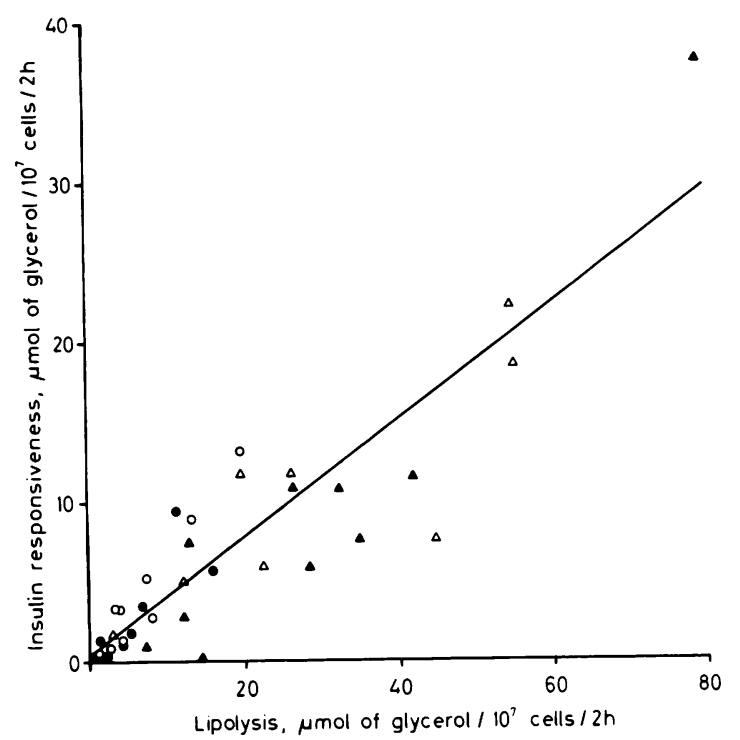

Figure 6. The relationship between the rate of lipolysis in the absence of insulin and insulin responsiveness in isolated fat cells of 10 nonobese (solid symbols) and 9 obese (open symbols) subjects. Fat cells were obtained after an overnight fast and incubated in the manner described in the legends to Figs. 4 and 5. The rate of basal (circles) and isoprenaline-induced (triangles) rates of glycerol release are shown on the $\mathrm{x}$ axis. Insulin responsiveness is shown on the $\mathrm{y}$ axis and was calculated as the rate of glycerol release in the absence of insulin minus the rate of glycerol release at the maximum effective insulin concentration. The line corresponds to the linear regression analysis of the whole material, $r=0.895 ; P<0.001$. The $F$ distribution test was used for a statistical comparison of the results in the obese vs. the control subjects, $F=1.40$, NS; and in the basal state vs. isoprenaline studies, $F=2.88$, NS.

obesity. Site differences in the antilipolytic effect of insulin have recently been demonstrated in nonobese subjects (27). Previously, only Pedersen et al. (6) had investigated gluteal fat. The other studies were performed by using femoral (19) or abdominal (23) fat.

In theory, there may be an association between the sensitivity of the antilipolytic effect of insulin and the rate of lipolysis, since a positive correlation between these two factors has been demonstrated in normal weight subjects (19). The present findings on insulin sensitivity in obese subjects who fasted overnight cannot, however, be explained on the basis of the lipolysis rate in the absence of insulin. First, in the isoprenaline experiments, increased insulin sensitivity was observed in obesity although the rate of isoprenaline-induced lipolysis was similar in obese and nonobese subjects. Secondly, there was no association between the individual $\mathrm{ED}_{50}$ values for insulin and the rate of lipolysis in the absence of insulin.

It has been inferred that changes in insulin sensitivity and insulin receptor binding are related (3). However, Häring et al. (28) demonstrated that insulin sensitivity of rat fat cells decreased after ATP depletion without a concomitant change in insulin receptor binding. The present results concerning antilipolysis in obese subjects who fasted overnight cannot be attributed to abnormalities in insulin receptor stoichiometry. Insulin receptor binding showed no change in obese subjects when expressed per fat cell number, but was significantly decreased when expressed per cell surface area. This agrees with recently published data (6). Olefsky (4) has also demonstrated a reduced insulin binding per fat cell number in obese subjects. However, the discrepancy in results may be more apparent than real. Our obese subjects had moderate fasting hyperinsulinemia and the onset of obesity occurred in childhood, two factors which may be associated with a less severe inhibition of insulin binding. Furthermore, there may be regional differences in the influence of obesity on insulin binding to human adipocytes. We and Pederson et al. (6) investigated gluteal cells, whereas Olefsky (4) studied abdominal adipocytes. It has recently been observed in obese women that maximum adipocyte insulin-binding capacity is more than twice as high in the former as in the latter cells (29). It is not known whether the total insulin receptor number per cell or the receptor density (number per unit cell surface area) is more important for the antilipolytic effect of insulin. In any case, the presently observed increase in insulin sensitivity can be explained only by an alteration at postreceptor levels of the antilipolytic action of insulin in obesity.

Although it is well known that the circulating level of free fatty acids is increased in fasting obese subjects (7), the effect of insulin on this parameter in these subjects is not clear. However, caution must be exercised in extrapolating the present in vitro findings to circulating free fatty acids in vivo. We investigated glycerol release, which is an accurate index of the lipolysis rate, since glycerol is not metabolized by human fat cells (7). Plasma free fatty acid levels, on the other hand, reflect the sum of lipolysis and the utilization by fat and other tissues. Furthermore, there are important interindividual and diurnal variations in plasma free fatty acids $(7,30)$. These variations are most marked during the morning hours (30) when the present study was performed.

Insulin resistance in obesity and other clinical conditions have been attributed to chronic changes in the action of the hormone, which develop slowly $(1,2)$. Recently, it has been demonstrated that glucose ingestion mediates a rapid increase in the insulin effect on human (10) and rat (31) adipocytes, which may be an important moderating factor for insulin action on these cells. In the present study as in the previous one (10), it was observed that the sensitivity of the antilipolytic effect of insulin was markedly enhanced in adipocytes obtained from nonobese subjects at $1 \mathrm{~h}$ after an $100 \mathrm{~g}$ oral glucose load. The results with insulin receptor binding indicate that the acute moderating effect of oral glucose was mainly the result of a postreceptor alteration of insulin sensitivity. In the fat cells of obese subjects, however, oral glucose did not stimulate the antilipolytic effect of insulin. Thus, a defect in the short-term regulation of insulin action in human obesity is strongly suggested. 
The further increase in body weight in obesity, in spite of resistance to insulin action on glucose metabolism, is a perplexing finding. However, only a minute part of ingested glucose is metabolized by human adipose tissue (32). In obesity, both the fasting and the postprandial insulin levels are increased. This, coupled with the increased sensitivity of antilipolysis in fasting and normal sensitivity after glucose ingestion, suggest that lipolysis is more suppressed in obese than in nonobese subjects under all physiological circumstances. This may explain why increase adipose mass and fat cell size continue to increase in obese subjects in spite of "insulin-glucose" resistance.

\section{Acknowledgments}

This study was supported by grants from the Swedish Medical Research Council, the Karolinska Institute, the Swedish Medical Association, the Nordic Insulin Foundation, the Swedish Diabetes Association, and the Osterman and Folksam Research Foundations.

\section{References}

1. Olefsky, J. M. 1981. Insulin resistance and insulin action. An in vitro and in vivo perspective. Diabetes. 30:148-162.

2. Olefsky, J. M., and O. G. Kolterman. 1981. Mechanisms of insulin resistance in obesity and non-insulin-dependent (type II) diabetes. $\mathbf{A m}$. J. Med. 70:151-168.

3. Kahn, C. R. 1978. Insulin resistance, insulin insensitivity and insulin unresponsiveness: a necessary distinction. Metab. Clin. Exp. 27:1893-1902.

4. Olefsky, J. M. 1976. Insulin binding to adipocytes and circulating monocytes from obese patients. J. Clin. Invest. 57:1165-1172.

5. Ciaraldi, T. P., O. G. Kolterman, and J. M. Olefsky. 1981. Mechanism of the postreceptor defect in insulin action in human obesity. Decrease in glucose transport system activity. J. Clin. Invest. 68:875880.

6. Pedersen, O., E. Hjöllund, and N. S. Sörensen. 1982. Insulin receptor binding and insulin action in human fat cells: effects of obesity and fasting. Metab. Clin. Exp. 31:884-895.

7. Björntorp, P., and J. Östman. 1971. Human adipose tissue. Dynamics and regulation. Adv. Metab. Disord. 5:277-327.

8. Björkhem, I., P. Arner, A. Thore, and J. Östman. 1981. Sensitive kinetic bioluminescent assay of glycerol release from human fat cells. J. Lipid. Res. 22:1142-1147.

9. Arner, P., J. Bolinder, and J. Östman. 1983. Glucose stimulation of the antilipolytic effect of insulin in humans. Science (Wash. DC). 220:1057-1059.

10. Arner, P., J. Bolinder, and J. Östman. 1983. Marked increase in insulin sensitivity of human fat cells one hour after glucose ingestion. J. Clin. Invest. 71:709-714.

11. Arner, P., O. Arner, and J. Östman. 1973. The effect of local anaesthetic agents on lipolysis by human adipose tissue. Life Sci. 13:161169.

12. Coburn, H. J., and J. J. Carrol. 1973. Improved manual and automated colorimetric determination of serum glucose with use of hexokinase and glucose-6-phosphate-dehydrogenase. Clin. Chem. 19:127-130.

13. Wide, L., R. Axen, and J. Porath. 1967. Radioimmunosorbent assay for proteins. Chemical couplings of antibodies to insoluble dextran. Immunochemistry. 4:381-386.
14. Rodbell, M. 1964. Metabolism of isolated fat cells. I. Effects of hormones on glucose metabolism and lipolysis. J. Biol. Chem. 239:375380.

15. Glieman, J., and O. Sonne. 1978. Binding and receptor-mediated degradation of insulin in adipocytes. J. Biol. Chem. 253:7857-7863.

16. Bolinder, J., J. Östman, and P. Arner. 1982. Post-receptor defects causing insulin resistance in normoinsulinemic non-insulin-dependent diabetes mellitus. Diabetes. 31:911-916.

17. Sjöström, L., P. Björntorp, and J. Vrana. 1971. Microscopic fatcell size measurements of frozen-cut adipose tissue in comparison with automatic determinations of osmium-fixed fat cells. J. Lipid. Res. 12:521530.

18. Hirsch, J., and E. Gallian. 1968. Methods for the determinations of adipose cell size and cell number in man and animals. J. Lipid. Res. 9:110-119.

19. Arner, P., J. Bolinder, P. Engfeldt, and J. Östman. 1981. The antilipolytic effect of insulin in human adipose tissue in obesity, diabetes mellitus, hyperinsulinemia and starvation. Metab. Clin. Exp. 30:753760.

20. Scatchard, G. 1949. The attraction of proteins for small molecules and ions. Ann. NY. Acad. Sci. 51:660-672.

21. Neter, J., and W. Wasserman. 1974. Comparison of two regression lines. In Applied Linear Statistical Models. R. D. Irwin, editor. University of Illinois Press, Champaign, IL. 160.

22. Klotz, J. M. 1982. Numbers of receptor sites from Scatchard graphs: facts and fantasies. Science (Wash. DC). 217:1247-1249.

23. Jacobsson, B., G. Holm, P. Björntorp, and U. Smith. 1976. Influence of cell size on the effects of insulin and noradrenaline on human adipose tissue. Diabetologia. 12:69-72.

24. Ohisalo, J. J. 1981. Effects of adenosine on lipolysis in human subcutaneous fat cells. J. Clin. Endocrinol. Metab. 52:359-363.

25. Burns, T. W., P. E. Langley, B. E. Terry, and G. A. Robinson. 1978. The role of free fatty acids in the regulation of lipolysis by human adipose tissue cells. Metab. Clin. Exp. 12:1755-1762.

26. Schwabe, U., P. S. Schönhöfer, and R. Ebert. 1974. Facilitation by adenosine of the action of insulin on the accumulation of adenosine 3':5'-monophosphate, lipolysis and glucose oxidation in isolated fat cells. Eur. J. Biochem. 46:537-545.

27. Bolinder, J., L. Kager, J. Östman, and P. Arner. 1983. Differences at the receptor and postreceptor levels between human omental and subcutaneous adipose tissue in the action of insulin on lipolysis. Diabetes. 32:117-123.

28. Häring, H. U., F. Rinninger, and W. Kemmler. 1981. Decreased insulin sensitivity due to a post-receptor defect as a consequence of ATP-deficiency in fat cells. FEBS (Fed. Eur. Biochem. Soc.) Lett. 132:235-238.

29. Bolinder, J., P. Engfeldt, J. Östman, and P. Arner. 1983. Site differences in insulin receptor binding and insulin action in subcutaneous fat of obese females. J. Clin. Endocrinol. Metab. 57:455-461.

30. Schlierf, G., and E. Dorow. 1973. Diurnal patterns of triglycerides, free fatty acids, blood sugar, and insulin during carbohydrate induction in man and their modification by nocturnal suppression of lipolysis. $J$. Clin. Invest. 52:1732-1740.

31. Livingston, J. N., and R. T. Moxley, III. 1982. Glucose ingestion mediates a rapid increase in the insulin responsiveness of rat adipocytes. Endocrinology. 111:1749-1751.

32. Björntorp, P., and L. Sjöström. 1978. Carbohydrate storage in man: speculations and some quantitative considerations. Metab. Clin. Exp. 27:1853-1865.

33. Documenta Geigy. 1970. Scientific Tables. Geigy Pharmaceuticals, Basel, Switzerland. Seventh ed. 